МИКОЛАєЦЬ В.А.

\title{
ОСОБЛИВОСТІ ТИПОВИХ СПРАВ В АДМІНІСТРАТИВНОМУ СУДОЧИНСТВІ
}

\begin{abstract}
У статті проаналізовано роль і значення типових справ в адміністративному судочинстві. Досліджено специфіку цих справ. Розкрито зміст і значення кожної із особливостей типових справ в адміністративному судочинстві. Визначено, що типові справи в адміністративному судочинстві мають такі ознаки: подібність характеристик позивачів (яка дозволяє виокремити групу позивачів, чиї справи будуть типовими, та виражається у окремому правовому статусі особи, яка звернулась до суду за захистом своїх порушених прав); ідентичність відповідача (на стороні відповідача повинен бути один суб'єкт владних повноважень або його відокремлений чи структурний підрозділ); аналогічність підстав позову (орган владних повноважень повинен аналогічно неправильно тлумачити норму права або дотриматись аналогічно неправомірної поведінки); єдність правового регулювання (суспільні відносини повинні регулюватись одними і тими самим нормами права, тобто в межах одних правовідносин); аналогічність позовних вимог (позивачі повинні обрати аналогічний спосіб захисту своїх справ, тобто заявити вимоги щодо поновлення своїх порушених прав у аналогічний спосіб); множинність (для визнання справи типовою їі характерні ознаки повинні відповідати як мінімум одній іншій справі). 3'ясовано, що предметом адміністративного позову є вимога позивача до суду про захист його прав або законних інтересів шляхом задоволення матеріально-правової претензії до відповідача. Правильне визначення предмету позову має важливе практичне значення, тому що предмет позову визначає сутність вимоги, 3 якою суд повинен дати відповідь у рішенні. Таким чином, переслідуючи мету поновлення порушених прав, особа, вказуючи у позові його предмет, тобто конкретні вимоги, на задоволення яких вона очікує, визначає конкретний спосіб поновлення iii порушених прав. Наголошено, що кожна особа самостійно визначає найбільш оптимальний спосіб, який, на іiї думку, зможе гарантувати поновлення порушеного права. При цьому подібні порушення прав з боку відповідача можуть бути поновлені у різні за свої характером способи, які особи вважають ефективними.
\end{abstract}

Ключові слова: типові справи, адміністративне судочинство, адміністративне законодавство, правосуддя, суд.

In the article the role and significance of typical cases in administrative proceedings are analyzed. The specifics of these cases are studied. The content and significance of each of the features of typical cases in administrative proceedings are revealed. It is determined that typical cases in administrative proceedings have the following features: similarity of characteristics of plaintiffs (which allows to distinguish a group of plaintiffs whose cases will be typical, and is expressed in a separate legal status of a person who applied to the court to protect their violated rights); identity of the defendant (on the side of the defendant there should be one subject of power, or its separate or structural subdivision); similarity of the grounds of the claim (the authority must similarly misinterpret the rule of law or adhere to similarly illegal behavior); unity of legal regulation (public relations should be regulated by the same rules of law, ie within the same legal relations); similarity of claims (plaintiffs must choose a similar way of defending their cases, ie to claim the restoration of their violated rights in a similar way); plurality (for a case to be considered typical, its characteristics must correspond to at least one other case). It was

(C) МИКОЛАЄЦЬ В.А. - кандидат юридичних наук, докторант (Міжрегіональна Академія управління персоналом) 
found that the subject of the administrative lawsuit is the plaintiff's claim to the court to protect his rights or legitimate interests by satisfying the substantive claim against the defendant. The correct definition of the subject of the claim is of great practical importance, because the subject of the claim determines the essence of the claim with which the court must respond in the decision. Thus, pursuing the purpose of restoring the violated rights, the person, indicating in the claim its subject, ie the specific requirements for which he expects, determines a specific way to restore his violated rights. It is emphasized that each person independently determines the most optimal way, which in his opinion can guarantee the restoration of the violated right. In this case, such violations of rights by the defendant may be renewed in different ways, which individuals consider effective.

Key words: typical cases, administrative proceedings, administrative legislation, justice, court.

Вступ. У науковій доктрині ознаки, тобто риси, властивості, особливості [1, с. 655], типових справ не стали предметом активного наукового інтересу вчених. Так, Н.В. Шелевер зазначає, що ознаками типової адміністративної справи $є$ такі:

1) відповідачем у такій справі $є$ винятково один і той самий суб'єкт владних повноважень або ж його відокремлені підрозділи (тобто орган державної влади чи орган місцевого самоврядування, їх посадова чи службова особа, а також інший суб'єкт під час здійснення ними публічно-владних управлінських функцій на підставі законодавства, в тому числі на виконання делегованих повноважень, або надання адміністративних послуг);

2) спір у такій справі виник з аналогічних підстав;

3) вказані суспільні відносини регулюються одними й тими самими нормами права;

4) позивачами у таких справах заявлено аналогічні позовні вимоги [2, с. 289].

Вважаємо, що відповідні ознаки цілком відображають риси та особливості типових адміністративних справ. Відповідні ознаки повністю корелюються із позиціями дослідників щодо визначення поняття типових адміністративних справ, отже, можемо зробити висновок, що відповідні наведені ознаки відповідають законодавчо встановленому визначенню типових справ. В той же час слід зазначити, що наведений перелік не є повним.

Постановка завдання. Метою статті $є$ розгляд ролі та значення типових справ в адміністративному судочинстві.

Результати дослідження. Верховний суд у складі судді-доповідача В.М. Кравчука та суддів М.М. Гімона, М.І. Гриціва, Н.В. Коваленко, О.П. Стародуба в рішенні від 04.04.2018 № № 822/524/18 вказав, що ознаками цієї типової справи є: а) позивач - особа, яка займає (або займала) посаду держслужби та якій встановлена інвалідність; б) відповідач - територіальний орган Пенсійного фонду України; в) предмет спору - вимога зобов'язати відповідача призначити пенсію по інвалідності державного службовця відповідно до ст. 37 Закону України від 16.12.1993 № 3723 «Про державну службу» [3]. Верховний Суд у складі колегії суддів Касаційного адміністративного суду: головуючого судді: В.М. Бевзенка, суддів - Н.А. Данилевич, І.Л. Желтобрюх, Т.Г. Стрелець, В.М. Шарапи, в рішенні від 16.05.2019 у справі № 620/4218/18 відніс до ознак типової справи: позивача, відповідача, підстави спору, предмет спору, відносини, що регулюються одними нормами права, а також аналогічні вимоги, що було заявлено позивачами [4]. Таким чином, аналіз постанов Верховного суду у зразкових справах показав, що до цього переліку також додається інформація про позивача, як одна із ознак типових справ.

Водночас слід наголосити, що для визначення сторони позивача з метою встановлення типових справ зазначається певна характеристика позивача, яка може бути релевантною по відношенню до великої кількості осіб. Так, Верховний суд у рішенні від 06.08.2019 № Пз/9901/12/19 під час визначення ознак типових справ вказав, що позивачами $є$ особи, звільнені з військової служби, які отримують пенсію відповідно до Закону України «Про пенсійне забезпечення осіб, звільнених з військової служби, та деяких інших осіб» [5]. У рішенні від 03.05.2018 у справі № 805/402/18 вказав, що позивачем у цій категорії справ $є$ пенсіонер, якому / якій призначено пенсію згідно із Законом № 1058-IV та який / яка $\epsilon$ внутрішньо переміщеною особою [6]. У рішенні від 21.01.2019 у справі № 240/4937/18 Верховний суд вказав, що (а) позивач $є$ особою, яка постраждала внаслідок Чорнобильської катастрофи; (б) позивач проживає на території радіоактивного забруднення внаслідок Чорнобильської катастрофи; (в) позивач є непрацюючим пенсіонером [7]. Отже, обов'язковою ознакою типової справи також є сторона позивача, а саме від- 
повідні ознаки позивача, які можуть встановити та визначити окрему їх групу. Очевидним є той факт, що до окремо узятого органу влади $є$ значна кількість позовів від різних позивачів, однак для точної кваліфікації таких справ як типових слід визначити окремі ознаки групи позивачів, щодо яких зразкове рішення буде релевантним та підлягатиме застосуванню.

Таким чином, характеристика позивача, тобто особи, на захист прав, свобод та інтересів якої подано позов до адміністративного суду, а також суб'єкта владних повноважень, на виконання повноважень якого подано позов до адміністративного суду, є ознакою типової адміністративної справи.

Ще однією ознакою типових адміністративних справ, на нашу думку, є множинність. Ця ознака випливає з того, що загалом типовість $є$ поєднанням в одному явищі індивідуальних, своєрідних рис, ознак і властивостей, характерних для сукупності явищ [8, с. 118]. Тобто для того, щоб справи були типовими, їх повинна бути певна сукупність. Якщо всі справи, які складають відповідну сукупність, відповідають окремим обов'язковим ознакам, $є$ підстави вважати, що відповідні справи $є$ типовими. 3 іншого боку, якщо відсутні інші справи, то одна справа не може визначатись типовою, оскільки її ознаки не є характерними для інших справ.

Враховуючи наведене вище, можемо відзначити, що типові справи мають такі ознаки:

1) подібність характеристик позивачів (яка дозволяє виокремити групу позивачів, чиї справи будуть типовими, та виражається в окремому правовому статусі особи, яка звернулась до суду за захистом своїх порушених прав).

2) ідентичність відповідача (на стороні відповідача повинен бути один суб'єкт владних повноважень або його відокремлений чи структурний підрозділ).

3) аналогічність підстав позову (орган владних повноважень повинен аналогічно неправильно тлумачити норму права або дотриматись аналогічно неправомірної поведінки).

4) єдність правового регулювання (суспільні відносини повинні регулюватись одними i тими самим нормами права, тобто в межах одних правовідносин).

5) аналогічність позовних вимог (позивачі повинні обрати аналогічний спосіб захисту своїх справ, тобто заявити вимоги щодо поновлення своїх порушених прав у аналогічний спосіб).

6) множинність (для визнання справи типовою іiі характерні ознаки повинні відповідати як мінімум одній іншій справі).

1. Подібність характеристик позивачів.

А.В. Бречко виділяє три категорії позивачів у типовій адміністративній справі: 1) громадяни України, іноземці та особи без громадянства (фізичні особи); 2) підприємства, установи, організації (юридичні особи), що не є суб’єктом владних повноважень; 3) органи державної влади, інші державні органи, органи влади Автономної Республіки Крим, органи місцевого самоврядування, їх посадові і службові особи, інші суб'єкти під час здійснення ними владних управлінських функцій на підставі законодавства, в тому числі на виконання делегованих повноважень (суб'єкти владних повноважень) [9, с. 78]. Водночас О.Ф. Ситніков вказує, що позивачем у спорах публічно-правового характеру може виступати як фізична, так і юридична особа. Трапляються випадки, коли позивачем в одній справі можуть виступати дві й більше особи в результаті спільного пред’явлення позову. Обов'язкова співучасть передбачена й у випадках, коли права позивача у справі не можна визначити без встановлення прав інших суб'єктів спірних відносин, які можуть пред'явити позов на захист їх порушених прав та інтересів [10, с. 819]. Таким чином, під час визначення такої ознаки типових адміністративних справ, як подібність характеристик позивачів, перше, на що слід звертати увагу, - це відповідність одній з категорій, до якої належать відповідні позивачі, зокрема, $є$ позивачі фізичними чи юридичними особами. Додатково ця характеристика може бути уточнена, якщо надати особливі ознаки відповідним позивачам з метою виокремлення із більш загальних категорій - окремих. Так, наприклад, якщо позивачам - фізичним особам надати таку додаткову характеристику, як перебування на військовій службі, виокремлюється специфічна категорія позивачів - військовослужбовці. Отже, ознакою подібності характеристики позивачів для встановлення наявності типовості у справах буде саме проходження військової служби, а справи за позовами інших фізичних осіб не будуть типовими в цій категорії.

2. Ідентичність відповідача.

Досліджуючи ознаку ідентичності відповідача, слід враховувати класифікацію (види) суб'єктів правовідносин, які можуть набувати правосуб' єктності відповідача в адміністративному процесі:

1) фізичні особи - публічні службовці, посадові особи державних, комунальних підприємств, установ, організацій, представники самоврядних професій, приватні фізичні особи (громадяни, іноземці, особи без громадянства); 
2) юридичні особи публічного й приватного права - органи державної влади, державні органи, Національний банк України, органи влади Автономної Республіки Крим, органи місцевого самоврядування, підприємства приватної або колективної форми власності;

3) колективні утворення без статусу юридичної особи - МСЕК-и, експертні, атестаційні, ліквідаційні та інші комісії, структурні підрозділи органів державної влади, державних органів, органів влади Автономної республіки Крим, органи суддівського самоврядування (зокрема, збори суддів тощо), органів місцевого самоврядування [11, с. 180].

Разом з тим відзначимо, що належність відповідачів до однієї із вищенаведених категорій не $є$ достатнім для встановлення типовості адміністративних справ. Типовими справи будуть лише за умови, що позови направлені саме до одного суб'єкта владних повноважень або його структурних підрозділів, що є обов'язковою кваліфікуючою ознакою типових справ. Таким чином, спостерігається максимальна конкретизація особи відповідача із виокремленням окремого суб'єкта владних повноважень. Зокрема, позови, направлені до Державної фіскальної служби та Пенсійного фонду України, не можуть вважатись типовими, незважаючи на те, що відповідачами будуть органи державної влади. Водночас справи за позовами до Пенсійного фонду України та його територіального відділення у м. Києві будуть відповідати ознаці ідентичності відповідачів, відтак можуть бути визнані типовими в разі співпадіння усіх інших обов'язкових ознак.

3. Аналогічність підстав позову.

Вимоги позивача до суду про задоволення матеріально-правової претензії до відповідача повинні підтверджуватися підставою позову. I.O. Картузова відзначає, що у найбільш широкому смислі підставою позову визнають обставини, якими позивач обгрунтовує свої вимоги. До цих обставин може бути віднесено такий юридичний факт або їх сукупність, які: а) підтверджують наявність або відсутність спірних правовідносин між сторонами та наявність порушення прав, свобод та інтересів позивача; б) підтверджують належність спірного права позивачу [12, с. 358]. Своєю чергою А.В. Бречко під підставою (підставами) адміністративного позову розуміє обставини справи (юридичні факти) і норми права, які у своїй сукупності дають право особі звернутися до суду відповідної інстанції з вимогами до іншої особи [9, с. 369]. Ми цілком погоджуємось із вищенаведеними позиціями вчених щодо визначення підстав позову, які слід розуміти як певні юридичні факти, які мають окремі правові наслідки та можуть бути підставою для виникнення, припинення чи зміни правовідносин. Поряд із цим слід зауважити, що підстави позову не $\epsilon$ нормами права, на які посилається позивач, або доказами у справі, оскільки вони лише підтверджують виникнення юридичного факту, який став підставою для позову, та обгрунтовують неправомірність поведінки відповідача. Ознака аналогічності підстав позову проявляється саме у тотожності юридичних фактів, які розкриваються через певне порушення суб'єктами владних повноважень законодавчо встановленої поведінки, що мала окремі юридичні наслідки та порушила права позивача.

4. Єдність правового регулювання.

Ознака єдності правового регулювання полягає у поширенні на правовідносини, у яких виник спір, одних і тих самих норм законодавства. Ця ознака передбачає як аналогічність самих правовідносин, які виникли між позивачем та відповідачем, так і забезпечення однаковості наданих сторонам у справі можливостей щодо застосування правових норм.

Фактично як позивачі, так і відповідачі повинні мати однаковий обсяг прав та обов'язків в межах окремих правовідносин. Таким чином, вбачається тісний взаємозв'язок ознаки єдності правового регулювання із ознакою характеристики позивача, яка передбачає встановлення конкретного правового статусу особи, яка звертається до суду із позовом, який, поміж іншого, характеризується наданням особі певного обсягу прав.

На практиці під час встановлення єдності правового регулювання, яке визначає і правовий статус особи, і правовідносини, які виникли між сторонами спору, визначаються конкретні норми, в межах реалізації яких виник спір. Так, наприклад, Верховний суд вказав, що «спір виник з аналогічних підстав у відносинах, що регулюються одними нормами права (у зв'язку 3 припиненням територіальними органами Пенсійного фонду України виплати пенсії внутрішньо переміщеним особам з підстав, які не передбачені п. 1, 3- 5 ч. 1 ст. 49 Закону № 1058-IV)» [6]. Також допускається визначення загального направлення нормативного регулювання питання: «спір виник з аналогічних підстав у відносинах, що регулюються одними нормами права (у зв'язку з неперерахунком та невиплатою (із урахуванням раніше виплачених сум) пенсії позивачеві з 05 березня 2019 року з урахуванням 100 відсотків суми підвищення пенсії, визначеного станом на 01 березня 2018 року)» [5]. Тобто у разі встановлення, що правовідносини, в межах яких виник 
спір, регулюються одними і тими самими нормами права, є підстави вважати, що ознака єдності правового регулювання дотримана, що означає типовість адміністративних справ у разі дотримання інших обов'язкових ознак.

5. Аналогічність позовних вимог.

Одностайно не вирішено питання щодо мети, яку переслідує особа під час пред'явлення позову. Щодо цього Є.Г. Пушкар вказував, що переслідуються цілі звернення за судовим захистом і залучення винних осіб до відповідальності за правопорушення, а також встановлення фактів і обставин, що мають значення для здійснення суб'єктивних прав [13, с. 12]. Ми цілком погоджуємось із цією позицією, оскільки метою звернення до суду є саме необхідність особи у захисті їі порушеного права, яке може проявлятись у поновленні відповідного права, притягненні до відповідальності або встановленні окремих фактів, що надалі будуть мати значення для реалізації особою своїх прав.

Своєю чергою О.Ф. Ситніков вважає, що інтерес позивача в адміністративному процесі передусім пов'язаний із відновленням порушених прав, свобод та інтересів у сфері публічно-правових відносин [14, с. 821]. У цьому разі позиція є обгрунтованою, оскільки мета подання позову характеризується через призму інтересу самої особи, отже, логічним виглядає звернення до суду саме $з$ метою поновлення порушеного права. При цьому, на нашу думку, відповідне поновлення у правах може бути здійснене шляхом як надання можливості подальшої реалізації такого права, так і притягненням винної особи до відповідальності.

Саме через позитивний результат вирішення спору, тобто прийняття рішення на користь позивача, характеризується мета його подання. У разі задоволення позовних вимог порушене право позивача підлягає поновленню, таким чином, досягається мета, яку переслідував позивач звертаючись за судовим захистом.

Отже, предметом адміністративного позову є вимога позивача до суду про захист його прав або законних інтересів шляхом задоволення матеріально-правової претензії до відповідача. Правильне визначення предмету позову має важливе практичне значення, тому що предмет позову визначає сутність вимоги, з якою суд повинен дати відповідь у рішенні [15, с. 257]. Таким чином, переслідуючи мету поновлення порушених прав, особа, вказуючи у позові його предмет, тобто конкретні вимоги, на задоволення яких вона очікує, визначає конкретний спосіб поновлення ії̈ порушених прав. Відзначимо, що кожна особа самостійно визначає найбільш оптимальний спосіб, який, на іiі думку, зможе гарантувати поновлення порушеного права. При цьому подібні порушення прав з боку відповідача можуть бути поновлені у різні за свої характером способи, які особи вважають ефективними.

Отже, враховуючи, що під предметом позову розуміють матеріально-правові вимоги особи, яка звертається до адміністративного суду відповідної інстанції з позовом до відповідача $[9$, с. 370], відзначимо, що ознака аналогічності предмету позову характеризується обранням позивачами однакових способів захисту своїх порушених прав. Наприклад, оскаржуючи протиправну бездіяльність органів ДФС під час процедури відшкодування податку на додану вартість, особа може обрати способом поновлення порушених прав стягнення суми відшкодування або зобов'язання контролюючого органу вчинити необхідні реєстраційні дії з метою подальшої реалізації позивачем права на отримання відшкодування. В цьому разі, незважаючи на аналогічність порушення права позивача, способи поновлення його права не будуть аналогічні, відтак відповідні справи не можуть бути визнані типовими.

6. Множинність.

Множинність типових адміністративних справ проявляється у тому, що для визнання справ типовими їх повинно бути як мінімум більше однієї. 3 одного боку, для того, щоб визнати справу типовою, iї обов'язкові ознаки, такі як предмет, підстави, позивач та відповідач, повинні бути аналогічні відповідним ознакам іншої справи або справ. Відповідно, таке співпадіння неможливе за відсутності інших справ, з яким порівнюється відповідність ознак.

Поряд із цим необхідність наявності справ у кількості більше однієї також врегульовується на законодавчому рівні. Так, відповідно до вимог частини 1 статті 290 КАС України, якщо у провадженні одного або декількох адміністративних судів перебувають типові адміністративні справи, кількість яких визначає доцільність ухвалення зразкового рішення, суд, який розглядає одну чи більше таких справ, може звернутися до Верховного Суду з поданням про розгляд однієї з них Верховним Судом як судом першої інстанції.

Відзначається, що кількісний критерій для відмови у відкритті провадження за зразковою справою становить другу за чисельністю категорію. Йдеться про невелику кількість типових 
справ (3-12) у подібних правовідносинах, що не створює доцільність їх розгляду Верховним Судом як зразкових [16]. Таким чином, очевидним є той факт, що для подання однієї з типових справ на розгляд Верхового суду як зразкової обов'язковим $\epsilon$ наявність певної кількості типових справ. Водночас законодавець не встановлює конкретної кількості типових справ, необхідної для початку розгляду зразкової справи, залишаючи Верховному суду певне дискреційне повноваження щодо визначення достатності кількості типових справ з метою прийняття до провадження однієї із них як зразкової.

Висновки. Враховуючи, що інститут типових справ $\epsilon$ новелою адміністративного судочинства, він наразі не є предметом активного наукового інтересу. Вважаємо, що, враховуючи важливість цього інституту для системи адміністративного судочинства, проблематика, пов'язана із ним, $є$ достатньо актуальною та перспективною темою для подальших наукових досліджень у цій сфері. Особливої уваги заслуговують ознаки типових справ, адже саме на підставі їх оцінки суди мають можливість застосовувати порядок розгляду типових справ та застосування до них судового прецеденту у вигляді зразкових рішень Верховного суду.

\section{Список використаних джерел:}

1. Словник української мови : Т. 5. АН Української РСР, Ін-т мовознав. ім. О.О. Потебні ; редкол.: І.К. Білодід (голова) [та ін.]. Київ : Наук. думка, 1974.

2. Зразкові та типові справи - новела в адміністративному судочинстві. Шелевер Наталія Василівна. Закарпатські правові читання. Матеріали XI Міжнародної науково-практичної конференції (11-31 квітня 2019 р., м. Ужгород). Ужгородський національний університет; За заг. ред. О.Я. Рогача, Я.В. Лазура, М.В. Савчина. Ужгород : РІК-У, 2019. 372 с.

3. Рішення Верховного Суду від 04.04.2018 № № 822/524/18 (№ Пз/9901/23/18) щодо переведення з пенсії по інвалідності на пенсію державного службовця. URL: https://supreme.court.gov. ua/supreme/pro_sud/zrazkova-sprava/zrazkove_822_524_18. (дата звернення - 13.09.2019).

4. Рішення Верховного Суду від 16.05.2019 ㄲo Пз/9901/4/19 (№620/4218/18) щодо грошової компенсації за невикористану додаткову відпустку військовослужбовцям у період мобілізації. URL: https://supreme.court.gov.ua/supreme/pro_sud/zrazkova-sprava/zs_9901_4_19_rishenna. (дата звернення - 02.09.2019).

5. Рішення Верховного Суду від 06.08.2019 № Пз/9901/12/19 (№160/3586/19) щодо розстрочення виплат сум підвищеної пенсії військовослужбовців у відставці. URL: https://supreme. court.gov.ua/supreme/pro sud/zrazkova-sprava/zs 9901 12 19. (дата звернення - 01.09.2019).

6. Рішення Верховного Суду від 03.05.2018 №- 805/402/18 (№ Пз/9901/20/18) про припинення виплати пенсії внутрішньо переміщеній особі. URL: https://supreme.court.gov.ua/supreme/ pro_sud/zrazkova-sprava/zs_9901_20_18 (дата звернення - 01.09.2019).

7. Рішення Верховного Суду від 21.01.2019 № 240/4937/18 (№Пз/9901/55/18) щодо перерахунку пенсій постраждалому внаслідок Чорнобильської катастрофи. URL: https://supreme.court.gov.ua/supreme/pro_sud/zrazkova-sprava/zs_9901_55_18_240_21_01_2019. (дата звернення - 01.09.2019).

8. Словник української мови : [в 11 т.]. АН Української РСР, Ін-т мовознав. ім. О.О. Потебні ; редкол. : І.К. Білодід (голова) [та ін.]. Київ : Наук. думка, 1970-1980. Т. 10 : Т-Ф. ред. тому : А.А. Бурячок, Г.М. Гнатюк. 1979. 658 с.

9. Бречко А.В. Адміністративний позов як форма захисту прав, свобод та інтересів у сфері публічно-правових відносин. Актуальні проблеми державного управління. 2009. № 2. С. 366-372.

10. Ситніков, О.Ф. Особливості правового положення позивача в адміністративному судочинстві. Форум права. 2012. № 4. С. 819-823.

11. Попов Р.В. Права відповідача в адміністративному процесі як предмет захисту. Форум права. 2015. № 5. С. 177-185.

12. Картузова I.О. До проблеми адміністративного позову. Наукові праџі Наџіонального університету «Одеська юридична академія». 2013. Т. 13. С. 352-362.

13. Пушкар Е.Г. Право на обращение в суд за судебной защитой : дисс. ... доктора юрид. наук : 12.00.03. Пушкар Е.Г. ; Киевск. гос. ун-т им. Т.Г. Шевченка. Киев, 1984. 199 с.

14. Ситніков О.Ф. Особливості правового положення позивача в адміністративному судочинстві. Форум права. 2012. № 4. С. 819-823.

15. Мирошниченко Ю.М. Адміністративний позов: правова природа та сутнісна характеристика. Судова апелящія. 2008. № 3. С. 89-95.

16. Зразкові справи (аналітичний огляд). URL: https://supreme.court.gov.ua/userfiles/media/ Zrazkovi_spravi.pdf. (дата звернення: 01.09.2019). 